\title{
MENGELOLA TRANSFORMASI DIGITAL
}

\author{
Nisa Nurul Hikmah/2301947823/LB21 \\ Binus Business School \\ Management Study Program \\ Binus University, Indonesia \\ nisanurulhikmah@gmail.com
}

\begin{abstract}
ABSTRAK
Transformasi digital kini gencar dilakukan hampir semua perusahaan di seluruh dunia. Transformasi mengubah secara drastis tentang proses bisnis dalam hal melayani pelanggan dan operasional. Semakin suatu perusahaan bergantung kepada teknologi, maka akan semakin efisien dan efektif proses bisnis yang dilakukan. Meskipun teknologi komputer sebelumnya sudah hadir, namun konsep tranformasi digital dikategorikan sebagai hal yang baru. Perkembangan IoT (Internet of things) dan AI (Artificial Intelligence) semakin marak dilakukan untuk bisa mempercepat proses transformasi digital. Transformasi digital bukan hanya teknologi yang terlibat, namun transformasi digital adalah penyatuan dari teknologi, orang, dan bisnis. Kini, tranformasi digital telah hadir di setiap kehidupan kita dan sebagai manusia kita harus bisa mengelola dan mengendalikannya agar bisa tetap bisa menggunakannya dengan efektif dan efisien.
\end{abstract}

Kata Kunci: transformasi digital, perkembangan teknologi digital, teknologi digital, transformasi bisnis.

\section{PENDAHULUAN}

Sebelum adanya transformasi digital, penggunaan internet dan komputer memang sudah banyak dilakukan oleh perusahaan, namun proses bisnis masih belum terlalu efisien karena masih banyak menggunakan tenaga kerja untuk bisa membantu proses bisnis. Dengan adanya trasnformasi digital bisa mengurangi biaya untuk tenaga kerja karena proses bisnis yang dilakukan bisa dilakukan hanya dengan komputer atau robot. Karyawan akan semakin tergantikan sebagian oleh kehadiran robot atau komputer, maka dari itu sebagai manusia kita tidak bisa hanya memiliki satu kemampuan, karena jika satu kemampuan itu sudah bisa digantikan dengan komputer atau robot, tentunya kita akan kehilangan pekerjaan. Transformasi digital hampir mempengaruhi semua jenis bisnis, dari perusahaan rintisan sampai perusahaan global gencar melakukan transformasi digital. Maka dari itu transformasi digital harus kita kelola agar bisa saling menguntungkan bagi perusahaan maupun karyawan dan tidak merugikan siapapun.

\section{LITERATURE REVIEW}

Transformasi digital adalah penggunaan teknologi untuk mengubah bisnis konvensional atau tradisional menjadi digital. Setiap perusahaan di era kini sangat dianjurkan untuk mengubah proses bisnisnya 
menjadi digital karena banyak kelebihan yang akan didapatkan. Kini, hampir semua perusahaan baru langsung menerapkan go digital, maka dari itu untuk bisa bersaing, perusahaan yang sudah lama berdiri juga harus go digital karena hampir semua perusahaan di dunia sudah go digital. Transformasi digital bukan hanya berbicara tentang persaingan go digital, namun juga banyak memiliki kelebihan dan manfaat bagi team, budaya perusahaan, dan produktivitas perusahaan.

Elemen dari disrupsi digital:

1. Pergeseran dari product centric ke customer centric

2. Pergeseran dari mahal, berisiko tinggi, dan lambat memasarkan suatu produk ke murah, berisiko rendah, fast-to-market/fail. Dahulu sebelum adanya transformasi, untuk memasarkan suatu produk akan lebih banyak memakan biaya dibanding masa kini. Untuk memasarkan produk, mereka harus membuka toko terlebih dahulu untuk bisa dikenal produknya. Untuk itu pemasaran produk juga tidak bisa seluas sekarang, dulu hanya satu kota atau satu provinsi saja, namun kini produk bisa dikenal oleh seluruh dunia dan lebih cepat untuk bisa dipasarkan hanya dengan internet.

Contoh: penggunaan shoppee yang semakin meningkat karena promo gratis ongkir dan harga yang relatif lebih murah dibanding beli secara konvensional.

3. Pergeseran dari inovasi yang menguasai ceruk pasar terlebih dahulu, untuk memengaruhi arus utama dengan cepat

4. Pergeseran dari perkembangan produk yang panjang dan lama ke inovasi yang lebih cepat dan memakan waktu yang lebih singkat.

Contoh; sekarang sudah banyak perubahan model mobil dengan cepat dan tidak selambat dahulu yang butuh waktu 5-10 tahun untuk merancang perubahan model mobil.

Tranformasi digital adalah penyatuan dari tiga komponen. Bukan hanya bicara tentang teknologi, namun tranformasi digital adalah bicara tentang penyatuan orang, teknologi, dan bisnis. Hadirnya teknologi juga tetap harus dikendalikan oleh orang, teknologi tidak bisa berdiri secara sendiri. Struktur dan budaya kerja juga membantu dalam pengelolaan tranformasi digital agar sukses. Berbicara tentang faktor bisnis, strategi bisnis yang tepat akan membantu perusahaan dalam mensukseskan tranformasi digital. Elemen teknologi menjadi elemen utama dalam transformasi digital.

Alat atau komponen yang menunjang suatu bisnis dapat bertranformasi digital:

1. Cloud: Cloud adalah unit penyimpanan yang menyimpan semua file perusahaan. Cloud bisa memberikan akses yang cepat ke data yang dibutuhkan oleh karyawan karena bisa diakses dari perangkat apapun dengan koneksi internet

2. Artificial intelligence 
AI atau Artificial intelligence menurut Kompas.com adalah teknologi yang memungkinkan sistem komputer, perangkat lunak, program dan robot untuk "berpikir" secara cerdas layaknya manusia.

3. Internet of Things

IoT atau Internet of Things menurut sekawan media adalah suatu konsep atau program dimana sebuah objek memiliki kemampuan untuk mentransmisikan atau mengirimkan data melalui jaringan tanpa menggunakan bantuan perangkat komputer dan manusia.

4. Manajemen data

5. Analitik tingkat lanjut

6. Analitik data besar

7. Kecerdasan pelanggan

Contoh tranformasi digital adalah banyak hadirnya bank digital. di Indonesia kehadiran bank digital mengalami kenaikan dari tahun ke tahun. Contoh bank digital yang sudah hadir adalah Jenius (Bank BTPN), Bank Jago, Blu by BCA, TMRW, dan masih banyak lagi. Dahulu orang untuk membuka rekening perlu ke bank dan akan menghabiskan banyak waktu di bank karena perlu mengantri, namun kini untuk membuka rekening kita bisa hanya dengan perangkat seluler dan proses yang dilakukan kurang dari 1 jam bahkan hanya beberapa menit.

Selain bank, kini banyak perusahaan start up yang sudah dari awal menggunakan digital sebagai modal bisnis mereka. Contohnya adalah pemesanan berbagai kebutuhan hanya dengan melalui aplikasi seperti Gojek, Tokopedia, dan lain-lain. Baru- baru ini juga Tokopedia merger dengan Gojek sehingga kedua perusahaan tersebut menyatu dan saling berkolaborasi. Kini untuk pembayaran Tokopedia bukan lagi menggunakan OVO, namun sudah menggunakan Gopay. Kedua aplikasi tersebut saling terhubung dan terintegrasi satu sama lain.

\section{KESIMPULAN}

di era kini, tak bisa dipungkiri hampir semua bisnis harus bertransformasi digital dan harus menggunakannya dengan optimal agar proses bisnis bisa lebih efisien untuk meningkatkan penjualan dan meningkatkan layanan kepada pelanggan. Terobosan harus terus dilakukan agar perusahaan dapat bersaing dengan banyak perusahaan digital yang hadir. Perusahaan juga harus menyiapkan orang yang memang kompeten dalam bidang IT untuk bisa menunjang kebutuhan dan kesuksesan transformasi digital. Pada era transformasi digital, disamping bersaing perusahaan juga harus melakukan kolaborasi dengan perusahaan lain agar dapat saling belajar satu sama lain dan meningkatkan customer baru

\section{REFERENSI}

D. H. Syahchari, Lasmy, M. G. Herlina, H. Saroso, D. Sudrajat and H. K. W. Jordaan, "The Influence of Digital Employee Experience and Employee Agility: Do They Boost Firm's Effectiveness?," 2021 
International Conference on Information Management and Technology (ICIMTech), 2021, pp. 67-71, doi: 10.1109/ICIMTech53080.2021.9534976.

Saroso, H., Syahchari, D. H., Sudrajat, D., Lasmy, \& Herlina, M. G. (2021). Managing digital transformation dilemma with industrial mapping. Paper presented at the Proceedings of 2021 International Conference on Information Management and Technology, ICIMTech 2021, 165-170. doi:10.1109/ICIMTech53080.2021.9535025 Retrieved from www.scopus.com.

Anonym. (No date). Transformasi digital, Apa itu dan mengapa hal itu penting. Retrieved from https://www.sas.com/id_id/insights/data-management/digital-transformation.html . [Access on 19 Oct 2021].

Anonym. (2020). 5 Contoh Perusahaan yang Sukses Menerapkan Transformasi Digital. retrieved from https://sasanadigital.com/5-contoh-perusahaan-yang-sukses-menerapkan-transformasi-digital/ [Access on 19 Oct 2021]. 